\title{
Effect on Diagnostic Image Quality of 3D Warping Registration Algorithms for MR Angiography in the Lower Legs
}

\author{
Andrew Fagan \\ St. James's Hospital, Dublin \\ Daniel Foley \\ St. James's Hospital, Dublin \\ Jacinta Browne \\ Technological University Dublin, jacinta.browne@tudublin.ie
}

See next page for additional authors

Follow this and additional works at: https://arrow.tudublin.ie/scschphyart

Part of the Physics Commons

\section{Recommended Citation}

Fagan, A.J., Foley, D., Browne, J.E., Sheane, B., O'Driscoll, D., Sheehy, N., Meaney, J.F. : Effect on Diagnostic Image Quality of 3D Warping Registration Algorithms for MR Angiography in the Lower Legs. Physica Medica, Vol. 28, 4, 2012, p. 336. doi:10.1016/j.ejmp.2012.06.016

This Article is brought to you for free and open access by the School of Physics \& Clinical \& Optometric Science at ARROW@TU Dublin. It has been accepted for inclusion in Articles by an authorized administrator of ARROW@TU Dublin. For more information, please contact arrow.admin@tudublin.ie, aisling.coyne@tudublin.ie, gerard.connolly@tudublin.ie.

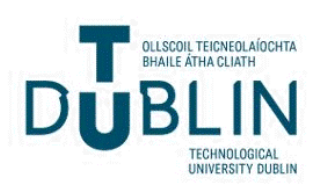




\section{Authors}

Andrew Fagan, Daniel Foley, Jacinta Browne, Barry Sheane, Dearbhail O'Driscoll, Niall Sheehy, and James Meaney

This article is available at ARROW@TU Dublin: https://arrow.tudublin.ie/scschphyart/48 


\title{
Effect on Diagnostic Image Quality of 3D Warping Registration Algorithms for MR Angiography in the Lower Legs
}

\author{
Andrew J. Fagan ${ }^{1,2}$, Daniel Foley ${ }^{1}$, Jacinta E Browne ${ }^{3}$, Barry Sheane ${ }^{1}$, Dearbhail \\ O'Driscoll ${ }^{1}$, Niall Sheehy ${ }^{1}$, James F. Meaney ${ }^{1}$ \\ ${ }^{1}$ Centre for Advanced Medical Imaging (CAMI), St. James's Hospital / Trinity College, \\ Dublin, \\ ${ }^{2}$ Medical Physics Dept, St. James's Hospital, Dublin \\ ${ }^{3}$ Medical Ultrasound Physics and Technology Group, School of Physics and FOCAS \\ Institute, Dublin Institute of Technology, Dublin
}

Mis-registration artefacts are known to reduce the image quality in contrast-enhanced MR angiography (CE-MRA), particularly whole body studies where table motion is involved. A previous in-house study revealed a significant improvement in image quality following use of a conventional registration algorithm. The aim of this study was to evaluate a new generation of algorithms specifically designed to deal with the signal intensity changes arising from the use of a contrast agent, as in CE-MRA.

Three warping algorithms were evaluated: AIR (used in the original study), and two algorithms (ITK and SEMI) designed for use with dynamic contrast enhanced MRI but not previously applied to MRA. $\quad 3$ T MR Images of 27 patients were acquired using a 3D-T ${ }^{-}$ weighted GRE sequence (resolution $0.9 \mathrm{~mm}^{3}$ ). Four expert observers visually assessed the images. Contrast-to-noise ratios were calculated using $C N R=\left(S I_{\text {Artery }}-S I_{\text {Tissue }}\right) / S D_{\text {Tissue }}$. A measure of vessel integrity was determined by segmenting out a vessel within a RoI for each patient and calculating the resulting vessel volume. Statistical analysis was performed using the Friedman nonparametric analysis on ranks for the clinical evaluation, and a paired-sample t-test was used to analyse the CNR and vessel volume for each algorithm.

Each algorithm was found by all observers to improve the image quality $(\mathrm{p}<0.05)$, with SEMI judged to perform better than AIR by all $(\mathrm{p}<0.05)$, while Slicer was found to be better than AIR by 3 out 4 of the observers $(\mathrm{p}<0.05)$. The improvement of SEMI compared to Slicer was significant only for one observer $(\mathrm{p}<0.05)$. Although AIR removed more background tissue signal than SEMI or Slicer, it was found to degrade the vessel sharpness and integrity. AIR and SEMI had a significantly higher CNR than Slicer, however no significant difference existed between AIR and SEMI. Both SEMI and Slicer had larger vessel volumes on the segmented datasets compared to AIR, illustrating the degradation of the vessel integrity caused by the AIR algorithm.

In conclusion, the conventionally-used AIR algorithm is not suitable for use in MRA image registration. However, a newer generation of algorithms designed to deal with signal intensity changes demonstrate significant potential for application to MRA. 